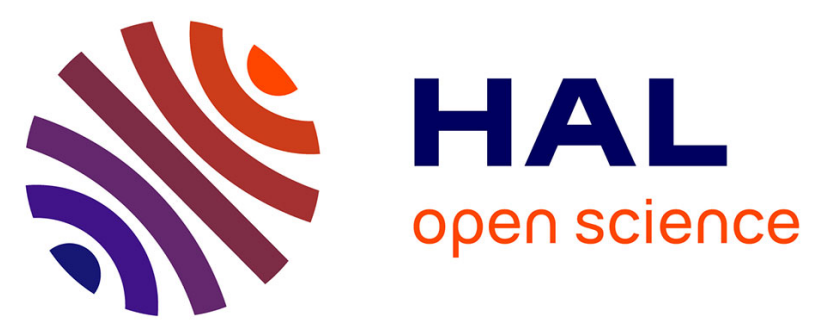

\title{
SECONDARY STRUCTURE SIMULATIONS OF TWIN-ARGININE SIGNAL PEPTIDES IN DIFFERENT ENVIRONMENTS
}

\author{
Miguel A. San-Miguel, Colin Robinson, Mark Rodger
}

\section{- To cite this version:}

Miguel A. San-Miguel, Colin Robinson, Mark Rodger. SECONDARY STRUCTURE SIMULATIONS OF TWIN-ARGININE SIGNAL PEPTIDES IN DIFFERENT ENVIRONMENTS. Molecular Simulation, 2009, 35 (12-13), pp.1033-1042. 10.1080/08927020902974063 . hal-00530453

\section{HAL Id: hal-00530453 \\ https://hal.science/hal-00530453}

Submitted on 29 Oct 2010

HAL is a multi-disciplinary open access archive for the deposit and dissemination of scientific research documents, whether they are published or not. The documents may come from teaching and research institutions in France or abroad, or from public or private research centers.
L'archive ouverte pluridisciplinaire $\mathbf{H A L}$, est destinée au dépôt et à la diffusion de documents scientifiques de niveau recherche, publiés ou non, émanant des établissements d'enseignement et de recherche français ou étrangers, des laboratoires publics ou privés. 


\section{SECONDARY STRUCTURE SIMULATIONS OF TWIN-ARGININE SIGNAL PEPTIDES IN DIFFERENT ENVIRONMENTS}

\begin{tabular}{|r|l|}
\hline Journal: & Molecular Simulation/Journal of Experimental Nanoscience \\
\hline Manuscript ID: & GMOS-2009-0019.R1 \\
\hline Journal: & Molecular Simulation \\
\hline Date Submitted by the \\
Author: & 20 -Mar-2009 \\
\hline Complete List of Authors: & $\begin{array}{l}\text { San-Miguel, Miguel; University of Sevilla, Department of Physical } \\
\text { Chemistry } \\
\text { Robinson, Colin; University of Warwick, Department of Biological } \\
\text { Sciences } \\
\text { Rodger, Mark; University of Warwick, Department of Chemistry }\end{array}$ \\
\hline Keywords: & Tat system, molecular dynamics, TFE, SufI \\
\hline &
\end{tabular}

\section{SCHOLARONE ${ }^{\mathrm{m}}$ Manuscripts}


1

2

3

4

5

6

7

8

9
SECONDARY STRUCTURE SIMULATIONS OF TWIN-ARGININE SIGNAL PEPTIDES IN DIFFERENT ENVIRONMENTS

\section{Miguel A. San-Miguel, ${ }^{*}$ Colin Robinson ${ }^{\dagger}$, P. Mark Rodger}

Department of Chemistry and ${ }^{\dagger}$ Department of Biological Sciences. University of Warwick Coventry CV4 7AL, UK

\section{ABSTRACT}

The twin-arginine translocation (Tat) system transports folded proteins across bacterial plasma membranes and the chloroplast thylakoid membrane. A twin arginine motif in the signal peptide sequence plays a key role in the signal process. In this article we report the results of molecular dynamics simulations on a typical E. coli RR-signal peptide and two mutant variants in both aqueous and trifluoroethanol (TFE) solutions. It has been found that the peptide switches between two distinct states: random coil in water and some helical content in TFE. Our simulations demonstrate that the wild-type peptide is considerably more flexible than either of the mutants in both the solvents investigated. The twin arginine motif was found to provide a nucleation point for the formation of an $\alpha$-helix in water, but also appears to destabilise $\alpha$-helices in other regions of the peptide when dissolved in TFE.

KEYWORDS: Tat system; MD; TFE; SufI.

"Corresponding author. E-mail address: smiguel@us.es Permanent address: 
Protein translocation processes across biological membranes have attracted considerable attention from scientists, particularly during the last two decades $[1-7]$. Because membrane bilayers are tightly sealed, and in many cases impermeable even to inorganic ions, sophisticated systems have evolved to accomplish the difficult process of transporting large globular proteins in a highly specific manner. It had been believed that the translocation process required the proteins to unfold - either prior to, or during, translocation across the membrane. However, within the last decade studies on thylakoid protein targeting identified a novel protein translocase, which facilitates translocation in the folded state [8-9]. This translocation mechanism has since been shown to operate in a wide variety of bacteria, chloroplasts and plant mitochondria [10, The system recognises proteins bearing an aminoterminal signal peptide containing a twin-arginine (RR) motif and has been termed the twin-arginine translocase, or Tat system. Several mutagenesis studies have demonstrated that this RR signal peptide contains all of the information required for precise recognition by the Tat system, and have identified certain essential features of the sequence. Of particular importance is the presence of adjacent arginines at the junction between an $\mathrm{N}$-terminal basic domain and hydrophobic core domain, together with the presence of a strongly hydrophobic residue at the second or third position after the twin arginine [11-13]. However, while much is known about the required primary structure there is still little knowledge of the secondary structure. In a previous study [14] we analysed circular dichroism (CD) spectra of a typical Escherichia coli RR-signal peptide and two inactive mutant variants in different environments. It was found that in aqueous solvent the peptides are unstructured, whereas some $\alpha$-helix character (up to $c a .40 \%$ ) emerged in hydrophobic solvents. The CD showed no significant differences in percentage helical content for the active and inactive sequences. However, analogous molecular dynamics (MD) simulations [14] suggested that there were differences in the location of the $\alpha$-helix between the wild-type and the mutants, with only the wild-type peptide showing helix formation in the vicinity of the RR motif. From those results it was clear that the peptide structure switches between two distinct states according to the environment, and that the Tat motif appeared to effect rather subtle changes in the secondary structure associated with these two states. However, a more detailed study of the 
secondary structure and dynamics is required in order to characterise the nature of these variations.

In this paper we present the results of a detailed MD study of the structural and dynamical properties of an $E$. coli RR-signal peptide together with two mutations known to render the peptides inactive in translocation. The three peptides have been simulated in water and in trifluoroethanol (TFE) solution (an apolar environment that mimics the membrane bilayer).

Different isotropic solvents have been chosen in molecular modelling in the literature to create a hydrophobic environment surrounding the peptide similar to that experienced when inserted in the membrane. Some solvents used have been chloroform [15], methane [16], octane [17], hexane [18], and methanol [19].

However, TFE has gained popularity because for more than three decades has been used in CD and NMR studies of peptides in solution showing that it is a $\alpha$-helix promoting solvent [20-27].

More recently, Bemporad et al have analysed in detail the behaviour of different solutes inside a lipid membrane and they concluded that the membrane core does not behave like a simple liquid solvenţ [28].

The use of explicit membrane has also been extended to numerous studies although only when the protein structure is known. Since the dynamics is slower and the number of atoms involved use to be larger than in isotropic fluids, therefore the simulations become highly time consuming $[29-32]_{\text {. }}$

In this paper fully atomistic models of the solvent have been used in each case. The dynamical behaviour of the peptide, in particular, is found to differ substantially between the wild-type and the two inactive mutants, suggesting that a propensity for forming an $\alpha$-helix on binding to a membrane may be a key factor in determining Tat activity. In next section we describe the different peptides and solvent models used, and give details of the simulation methodology. Thereafter, we focus on the results obtained from the dynamics when the peptides are inserted into water, TFE or a vacuum; some of the implications of these results are also discussed. In the final section the main conclusions are briefly summarized.
Deleted: -

\begin{tabular}{|l|}
\hline Deleted: modeling \\
\hline Formatted: English U.K. \\
\hline Deleted: (Peter et al., 2000) \\
\hline Formatted: English U.K. \\
\hline Deleted: (Olivella et al., 2002) \\
\hline Deleted: (Tieleman et al., 2001) \\
\hline Formatted: English U.K. \\
\hline Deleted: (Chipot et al., 1999) \\
\hline Deleted: (Tieleman et al., 1999) \\
\hline Formatted: English U.K. \\
\hline Formatted: English U.K. \\
\hline Formatted: English U.K. \\
\hline Formatted: English U.K. \\
\hline Deleted: Very \\
\hline Formatted: English U.K. \\
\hline Deleted: . (Bemporad et al, 2004) \\
\hline Formatted: English U.K. \\
Deleted: . (Domene et al., 2004; \\
Tieleman et al., 2002; Tieleman and \\
Sansom, 2001; Forrest et al., 2000; La \\
Rocca et al., 1999; Tieleman et al., 1999)If \\
\hline Eormatted: English U.K. \\
\hline
\end{tabular}




\section{METHOD}

\subsection{PEPTIDES}

Molecular dynamics (MD) simulations have been performed in order to investigate the influence of the twin arginine motif on both the secondary structure and dynamical behaviour of SufI peptides in two different environments: aqueous and trifluoroethanol (TFE) solutions. The latter was chosen as it is known to be a membrane mimicking solvent.

The wild type sequence (SufI-RR) is

$4-$

\section{SufI-RR MSLSRRQFIQASGIALCAGAVPLKASA}

while the two mutants chosen for this study (SufI-KK) and SufI-AA) are

\section{SufI-KK MSLSKKQFIQASGIALCAGAVPLKASA \\ SUfI-AA MSLSRRQAAQASGIALCAGAVPLKASA}

Secondary structure predictions were carried out using a number of different protein structure prediction servers: PSIPRED [33], JPRED [34], Prof [35] and PHD [36]. All predicted an $\alpha$-helix in the central region, although each predicted a slightly different length. The PHD method gave what was essentially a consensus result and so was used in this work to construct the initial configurations for subsequent MD simulations. The coordinates and force field for all three peptides were constructed by using Quanta/CHARMm version 28 [37] and then exported to DL_POLY [38] format for the MD simulations. All the sequences included a right-handed $\alpha$-helix with a length of 16 amino acid residues, as predicted by the PHD method. Initial structures were optimised using the conjugate gradient method.

\subsection{SOLVATED STRUCTURES}

Each peptide conformation was then inserted into a solvent box (previously equilibrated at $300 \mathrm{~K}, 1 \mathrm{~atm}$ ) and all solvent molecules that overlapped with the peptide were removed; three additional solvent molecules were converted to $\mathrm{Cl}^{-}$ions to compensate for the charge of $+3 e$ on these peptides. The resulting system contained 3173 water molecules, or 990 TFE molecules, in a periodic truncated octahedral simulation box of maximum length 65 $\AA$ A. The system was then relaxed by (i) performing a 5 ps MD simulation at $300 \mathrm{~K}, 1 \mathrm{~atm}$ in which the peptide was treated as a rigid body, and (ii) performing a 2 ps MD simulation with
Deleted:

Formatted: English U.K.
Deleted: methods

Deleted: (McGuffin et al, 2000) Formatted: English U.K. Deleted: (Cuff et al, 1999) Formatted: English U.K. Deleted: (Ouali et al, 2000) Formatted: English U.K. Deleted: (Rost, 1996) Formatted: English U.K. Deleted: (Accelerys Inc.) Formatted: English U.K. Deleted: (Smith et al, 2002) Formatted: English U.K. 
a fully flexible peptide at $2 \mathrm{~K}$; these stages served to remove any strain introduced on solvation without destroying the initial secondary structure. A further $1 \mathrm{~ns}$ simulation in the water solvated systems and $6 \mathrm{~ns}$ simulation in the TFE system were then accumulated to study the evolution of the secondary structure. As will be shown in the next section, this time scale was sufficiently long for the water systems to converge to a steady random coiled state. Secondary structure was analysed using STRIDE [39].

This study does not intend to analyse the secondary structure of the sequences during extended periods of time, but the propensity of the peptides to change the initial secondary structure from different initial conditions during the first stage of exposition to two different environments.

\subsection{SIMULATION PROTOCOL}

All MD simulations were performed at constant temperature and pressure (NPT) using the Nosé-Hoover method $[40-41\rceil$ with thermostat and barostat relaxation constants of $0.5 \mathrm{ps}$ and $1.0 \mathrm{ps}$, respectively. A time step of $2 \mathrm{fs}$ was used in all calculations and the equations of motion were integrated using the leap frog algorithm $\lceil 42]$. Configurations were stored every 2 ps for statistical analysis.

The peptide was modelled with the CHARMM-22 force field [43] water with the rigid SPC model 5441 and TFE using the Model 5 reported by Chitra and Smith [27]; previous studies had shown the CHARMM potential for TFE to underestimate the stability of $\alpha$-helices $[14,45]$. Long range forces were evaluated using the reaction field method, with the explicit solvent sphere around each site having radius $15 \AA$ and a relative dielectric constant of 80 and 27 for water and TFE, respectively; all other non-bonded interactions were also truncated at a cutoff atom radius of $15 \AA$.

\subsection{SimULATIONS IN VACUUM}

In addition to the solvated systems, we have carried out simulations of the three sequences in vacuum. These have been used both to identify significant intramolecular interactions and to compare with solvent effects. Since the primary purpose of these vacuum simulations was to identify peptide configurations that were intrinsically stable, and not to simulate equilibrium properties, a temperature of $500 \mathrm{~K}$ was used to speed up the exploration of configuration space. Trajectories of $48 \mathrm{~ns}$ were generated and configurations saved every 2
Deleted: (Frishman et al, 1995) Formatted: English U.K.
Deleted: (Nosé, 1984; Hoover, 1985) Formatted: English U.K. Deleted: (Allen and Tildesley, 1987) Formatted: English U.K.

Deleted: (MacKerell et al, 1998) Formatted: English U.K. Deleted: (

Deleted: Berendsen et al, 1981) Formatted: English U.K. Deleted: (2001)

Formatted: English U.K.

Deleted: (Rodziewicz-Motowidio et al, 2002; San Miguel et al, 2003)

Formatted: English U.K. 
ps for statistical analysis. All charge-charge interactions were truncated at $15 \AA$ based on an atom-atom scheme within a direct coulombic approach.

\section{RESULTS}

\subsection{SUFIS IN WATER}

CD measurements of the SufI and the mutant peptides in water indicated that all sequences are random coils in water [14k Our MD simulations are in good agreement with this evidence. Figure 1 shows the number of aminoacid residues participating in an $\alpha$-helix at any given time. The starting configurations contain a 16-residue helix, but for each peptide this rapidly degrades to give a random coil structure. Some differences in the dynamics of the three peptide sequences are evident. The initial $\alpha$-helix is seen to decay 4-5 times faster in SufI-RR than in the inactive mutants, persisting for only $30 \mathrm{ps}$ in SufI-RR, but for about 110_$150 \mathrm{ps}$ in the two mutants. At the same time, SufI-RR shows a much greater propensity to reform the helices subsequently, with transient 6-residue $\alpha$-helices forming on at least 7 separate occasions during the time interval 400-800 ps. In contrast, subsequent helix reformation in SufI-KK was much less frequent (3 events) and gave shorter helices, while no subsequent secondary structure was observed in SufI-AA. Close inspection of these transient configurations showed that, for SufI-RR, the helix always appeared in the fragment between $\operatorname{Ser}(2)$ and $\operatorname{Arg}(6)$ and between $\operatorname{Leu}(3)$ and $G \ln (7)$, i.e. in the region of the key motif for the Tat translocation. In contrast, the transient helices in SufI-KK involved Ile(14) at $c a .250$ ps and $\mathrm{Ala}(18)$ at $750 \mathrm{ps}$.

The origin of these helices is the formation of strong intramolecular hydrogen bonds and so we have computed the number of intramolecular H-bonds within each peptide as a function of time; the results are plotted in Figure 2. As can be seen, the number of H-bonds fluctuates significantly, with most of the data indicating only short excursions during which more than one intra-molecular H-bond is found. The main exception to this is for SufI-RR between 550 and 650 ps. During this time interval, SufI-RR consistently shows two intramolecular H-bonds, and frequently as many as 4-5. This is precisely the time interval during which transient helices are seen to form in SufI-RR. (Figure 1)

The root mean square atomic displacements from the first configuration have also been calculated and are presented in Figure 3. Plots indicate that SufI-RR and SufI-AA change much more rapidly at the beginning than SufI-KK, which increases monotonically 
have reached a plateau region after $100 \mathrm{ps}$ but SufI-RR shows larger fluctuations around the mean value than SufI-AA.

\subsection{SUFIS IN TFE}

MD simulations of all three peptides in TFE have been carried out, each with a total duration of $6 \mathrm{~ns}$, and the time dependence of the resultant helix lengths is shown in Figure 4. In this case the mutant sequences retain most of the original secondary structure throughout the simulation: SufI-AA exhibits only minor fluctuations away from the 16 amino acid $\alpha-$ helix, while the helix in SufI-KK shortens slightly — initially to about 15 residues and then to 13 amino acids at about $3.5 \mathrm{~ns}$. The response of the wild-type sequence to immersion in TFE contrasts strongly with the stable helices observed in the mutants. The helix reduces to around 10 amino acids during the first $30-40 \mathrm{ps}$, and then at about $1.5 \mathrm{~ns}$ shortens again up to just four residues. Thereafter there are frequent fluctuations in the length of the helix, with values in the range 4-8 amino acids throughout the rest of the simulation. The length of these simulations is long enough to indicate different behaviour between the wild-type peptide and the mutants.

In our previous work we reported results from $\mathrm{CD}$ measurements where we found that the helical content in TFE was around $45 \%$ for all the peptides, although slightly higher for SufI-AA and slightly lower for SufI-KK than for SufI-RR. The simulations presented in this work predict a variation in helical content: 59\% for SufI-AA, $48 \%$ for SufI-KK and 25\% for SufI-RR. The results for SufI-AA and SufI-KK would seem to be in line with experiment, while the results for SufI-RR give too little helical content. In fact, both mutants and in particular SufI-AA, show almost no conformational changes on the simulation timescale keeping their initial helical content.

One point that emerges clearly from Figure 4 is that the wild-type peptide shows much greater flexibility than either of the mutants, and develops many different configurations with different helical content during the course of the simulation.

The assignment of secondary structure for each configuration in a trajectory also allows one to calculate the probability of finding each amino acid within an $\alpha$-helix, $P_{\alpha}$. The results are depicted in Figure 5. The plot for SufI-AA emphasises the lack of conformational change noted above, with unit probability of finding residues 3-17 forming an $\alpha$-helix. Similar stability is seen in residues $7-15$ of SufI-KK, although some breakdown of the $\alpha$ helix is seen on either side of these residues. In particular, there is substantial dip in $P_{\alpha}$ at the 
$6^{\text {th }}$ residue, i.e. at the second lysine mutation, that is not seen in the presence of the RR motif. SufI-KK also shows a small decrease in $P_{\alpha}$ for amino acids 16-17, corresponding to the changes evident at $c a .3 .5 \mathrm{~ns}$ in Figure 4. For SufI-RR, two different helix regions are identified. The first of these (which we shall denote by H1) is 4-6 residues long, and is centred on three amino acids (Arg-Arg-Gln) that include the twin arginine motif required for translocation. The second helix (H2) is centred on residues 15-17 (Ala-Leu-Cys), with transient involvement from the residues on either side of this region.

The time evolution of the helix distributions, $P_{\alpha}$, has been calculated by finding the average probabilities during successive $1 \mathrm{~ns}$ segments of the simulation. The results for SufI$\mathrm{RR}$ are shown in Figure 6 , Analogous plots are not presented for the mutants since they showed no significant variation with time. The two helix regions $(\mathrm{H} 1$ and $\mathrm{H} 2)$ are clearly defined at all times. The $\mathrm{H} 1$ region appears to have converged to an equilibrium distribution after $c a .2$ ns, with the helix present about $50 \%$ of the time. The secondary structure in the $\mathrm{H} 2$ region becomes more stable as the simulation continues, reaching a plateau of about $70 \%$ by $4-6$ ns.

Visual inspection of the trajectory indicates that a very stable interaction emerges between $\operatorname{Arg}(6)$ and $\operatorname{Gln}(10)$, and this probably stabilises the H1 region. A typical conformation is shown in Figure 7 and shows the presence of a second, intra-residue, H-bond within $\operatorname{Arg}(6)$ in addition to the one between $\operatorname{Arg}(6)$ and $\mathrm{Gln}(10)$. A long-lived H-bond is also seen in the $\mathrm{H} 2$ region, between a hydrogen atom in Cys(17) and oxygen atom in Ile(14) (Figure 7); this H-bond persisted throughout the whole simulation. In general, the total number of intra-peptide H-bonds was consistent with stability of the $\alpha$-helices, as noted above (Figure 8). No long-term changes are evident in the total number of H-bonds. SufI-RR presents the lowest number of H-bonds ( $8 \pm 4)$, whereas SufI-KK, which is the most stable structure, has $12 \pm 3$ and SufI-AA $10 \pm 3$.

The decreased stability, or increased flexibility, of the wild-type sequence relative to the two mutants is also seen in the atomic RMSDs (Figure 9 and Figure 10). SufI-RR shows the largest deviations for the whole peptide from the initial structure at all times. (Figure 9) The deviations can be assigned mainly to the atoms in the N-terminal and secondly to those ones in the H-domain. (Figure 10)

The number of dihedral transitions for the backbone angles $\varphi$ and $\psi$ have also been computed for every aminoacid residue in each peptide in TFE and they have been plotted in Figure 11. It can be seen that the number of $\psi$ transitions for most of the residues is only 
significant for SufI-RR, indicating a higher flexibility for this peptide. This fact can be related to the presence of the twin-arginine motif in the N-terminal region where the number of $\varphi$ and $\psi$ transitions is much higher than for the mutants,

\subsection{SUFIS IN VACUUM}

The dynamics of solvated proteins is a competition between intra-peptide forces and solute-solvent interactions. The absence of solvent in vacuum simulations leaves just the intra-peptide interactions to govern the dynamical behaviour, and so provides a useful comparison with the solvated calculations. We have therefore performed additional simulations of the various peptides in vacuum at $500 \mathrm{~K}$ in vacuum. Trajectories of $48 \mathrm{~ns}$ were generated and configurations stored every 2 ps for statistical analysis.

Figure 12 shows the helix length as a function of time. Very different behaviour is exhibited by the three sequences. The starting helix in SufI-RR decays to just four residues in the first nanosecond and then vanishes completely after $24 \mathrm{~ns}$, with a transient reappearance after $42 \mathrm{~ns}$. The mutants, on the other hand, exhibit substantial helix content during most of the trajectory, albeit with large, dynamic fluctuations in the helix length. The location of these $\alpha$-helices also shows interesting variations between the three peptides (see Figure 13 ). The $\alpha$-helix in SufI-RR tends to include the twin arginine motif, with a fairly homogeneous distribution along the rest of the peptide. In contrast, both the mutants show a bimodal distribution, with probably the dominant helix-forming tendency arising from residues 15-20.

From these results, we conclude that the wild-type sequence is considerably more flexible than either of the mutants, with much more frequent-albeit transient-variations in secondary structure. The twin arginine motif does appear to provide a nucleation point for the formation of an $\alpha$-helix, but does also appear to destabilise $\alpha$-helices in the middle of the peptide when dissolved in TFE.

\section{CONCLUDING REMARKS}

In this report, we have investigated the dynamical behaviour of the Tat signal peptide in a hydrophilic (water) and hydrophobic (trifluoroethanol, TFE) solvent. A wild-type SufI peptide and two mutant variants known to be inactive were examined.

In our previous study $\$ 14]$ circular dichroism measurements were performed and showed that the two non-functional peptides exhibit almost identical spectra to the wild-type SufI peptide in both solvents. In water, all the peptides were random coil structured, whereas in TFE, they showed a similar $\alpha$-helical content (up to about $45 \%$ ). In the same study our 
molecular dynamics simulations, in agreement with the experiments, indicated that SufI-RR and SufI-KK switch between two distinct states: random coil in water and helical structured in TFE. However, the $\alpha$-helical content predicted was for both sequences about $20 \%$, which is much lower than that one from the experiments. It was claimed that it might be caused by the TFE model used, which has been observed previously to underestimate the helical content. The fact that the helical extents were similar between the wild-type and the mutant lead us to conclude that the arginine sidechains, and not their contribution to the helical structure, are the critical factors in this class of peptide.

In this work we have explored all these issues and extended our study to all the mutants. First of all, we have adopted a more accurate TFE model. We have also chosen a longer electrostatic cut-off radius (extended up to $15 \AA$, instead of $10 \AA$ as in the previous work) to use in the reaction field method, taking into account explicitly a much higher number of interactions with neighbor residues and solvent molecules.

The simulations in water show that all the peptides rapidly lose the helical content during the first picoseconds. Surprisingly, transient $\alpha$-helices structures involving the twinarginine motif can be observed during the trajectory for SufI-RR but not for any of the mutants.

The new TFE model seems to provide a better description of the system and the helical content predicted are higher than in the previous work. Our results show no significant conformational changes in the mutants during 6 ns. However, SufI-RR exhibits many different configurations during the same timescale, thus showing a much greater flexibility. The analysis of its secondary structure demonstrates that all of these configurations contain $\alpha$-helices that involve the twin-arginine motif. These studies do not intend to explore the conformational changes in much extended periods of time, but the response of the system to insertion in two different solvents in the initial stages. Different repeats in the same timescale have showed similar results and demonstrate the different behaviour between the wild-type sequence and the mutants, which can be assigned to the only difference between the peptides: the presence of the twin arginine motif.

Extended simulations were performed in vacuum up to much longer timescales (48 ns). SufI-RR again showed a flexible behaviour, with frequent conformational changes, and helices forming around the key twin-arginine motif. The mutants, on the other hand, exhibit substantial helix content in a bimodal distribution during most of the trajectory, with 
probably the dominant helix-forming tendency arising in a different region from the twinarginine motif.

From our results, we conclude that the wild-type sequence is considerably more flexible than either of the mutants, with much more frequent variations in secondary structure. The twin arginine motif appears to provide a nucleation point for the formation of an $\alpha$-helix, but does also appear to destabilise $\alpha$-helices in other regions of the peptide when dissolved in TFE. Therefore, the presence of the twin arginine motif in the wild-type sequence does exert some control over the formation and stability of $\alpha$-helices within the peptide

\section{ACKNOWLEDGEMENTS}

This work was supported by Engineering and Physical Sciences Research Council grant GR/R36503. 
[1] G. Blobel and B. Dobberstein, Transfer of proteins across membranes. Presence of proteolytically processed and un processed nascent immunoglobulin light chains on membrane-bound ribosomes of murine myeloma, J. Cell Biol. 67 (1975), pp. 835-851.

[2] B. Jungnickel, T. Rapoport and E. Hartmann, Protein translocation: common themes from bacteria to man, FEBS Lett. 346 (1994), pp. 73-77.

[3] J.W. Izard and D.A. Kendall, Signal peptides: exquisitely designed transport promoters, Mol. Microbiol. 13 (1994), pp. 765-773.

[4] G. Schatz and B. Dobberstein, Common principles of protein translocation across membranes, Science 271 (1996), pp. 1519-1526.

[5] L. Heins, I. Collinson, and J. Soll, The protein transport apparatus of chloroplast envelopes, Trends Plant Sci. 3 (1998), pp. 56-61.

[6] R.E. Dalbey and C. Robinson, Protein translocation into and across the bacterial plasma membrane and the plant thylakoid membrane, Trends Biochem. Sci. 24 (1999), pp. 17-22.

[7] J.M. Hermann and W. Neupert, Protein transport into mitochondria, Curr. Opin. Microbiol. 3 (2000), pp. 210-214.

[8] S.A. Clark and S.M. Theg, A folded protein can be transported across the chloroplast envelope and thylakoid membranes, Mol. Biol. Cell 8 (1997), pp. 923-934.

[9] P.J. Hynds, D. Robinson, and C. Robinson, The Sec-independent twin-arginine translocation system can transport both tightly folded and malfolded proteins across the thylakoid membrane, J. Biol. Chem. 273 (1998), pp. 34868-34874.

[10] C. Robinson, and A. Bolhuis, Protein targeting by the twin-arginine translocation pathway, Nature Rev. Mol. Cell. Biol. 2 (2001), pp. 350-355.

[11] A.M. Chaddock, A. Mant, I. Karnauchov, S. Brink, R.G. Herrmann, R.B. Klösgen, and C. Robinson, A new type of signal peptide: central role of a twin-arginine motif in transfer signals for the $\Delta p H$-dependent thylakoidal protein translocase, EMBO J. 14 (1995), pp. 2715-2722.

[12] S. Brink, E.G. Bogsch, W.R. Edwards, P.J. Hynds, and C. Robinson, Targeting of thylakoid proteins by the $\Delta p H$-driven twin-arginine translocation pathway requires a specific signal in the hydrophobic domain in conjunction with the twin-arginine motif, FEBS Letts 434 (1998), pp. 425-430. 
[13] N.R. Stanley, T. Palmer, and B.C. Berks, The twin arginine consensus motif of Tat signal peptides is involved in Sec-independent protein targeting in Escherichia coli, J. Biol. Chem. 275 (2000), pp. 11591-11596.

[14] M. San-Miguel, R. Marrington, P.M. Rodger, A. Rodger, and C. Robinson, An Escherichia coli twin-arginine signal peptide switches between helical and unstructured conformations depending on the hydrophobicity of the environment, Eur. J. Biochem. 270 (2003), pp. 3345-3352.

[15] C. Peter, X. Daura, and W.F. van Gunsteren, Peptides of aminoxy acids: a molecular dynamics simulation study of conformational equilibria under various conditions, J. Am. Chem. Soc. $122(2000)$, pp. 7461-7466.

[16] M. Olivella, X. Deupi, C. Govaerts, and L. Pardo, Influence of the environment in the conformation of $\alpha$-helices studied by protein database search and molecular dynamics simulations, Biophys. J. 82 (2002), pp. 3207-3213.

[17] D.P. Tieleman, and M.S.P. Sansom, Molecular dynamics simulations of antimicrobial peptides: from membrane binding to trans-membrane channels, Int. J. of Quantum Chem. $\underline{83(2001), \text { pp. 166-179. }}$

[18] C. Chipot, B. Maigret, and A. Pohorille, Early events in the folding of an amphipathic peptide: a multinanosecond molecular dynamics study, Proteins: Structure, Function, and Genetics 36 (1999), pp. 383-399.

[19] D.P. Tieleman, M.S.P. Sansom, and H.J.C. Berendsen, Alamethicin helices in a bilayer and in solution: molecular dynamics simulations, Biophys. J. 76 (1999), pp. 40-49.

[20] D. Roccatano, G. Colombo, M. Fioroni, and A.E. Mark, Mechanism by which 2,2,2trifluoroethanol/water mixtures stabilize secondary structure formation in peptides: a molecular dynamics study, Proc. Natl. Acad. Sci. USA 99 (2002), pp. 12179-12184.

[21] M. Iovino, M. Falconi, A. Marcellini, and A. Desideri, Molecular dynamics simulation of the antimicrobial salivary peptide histatin-5 in water and in trifluoroethanol: a microscopic description of the water destructuring effect, J. Peptide Research 58 (2001), pp. 45-55.

[22] M. Fioroni, M.D. Diaz, K. Burger, and S. Burger, Solvation phenomena of a tetrapeptide in water/trifluoroethanol and water/ethanol mixtures: a diffusion NMR, intermolecular NOE, and molecular dynamics study, J. Am. Chem. Soc. 124 (2002), pp. 7737-7744.
Formatted: Font: Italic

Formatted: Font: Not Italic

Formatted: Font: Italic

Formatted: Font: Not Italic

Formatted: Font: Italic

Formatted: Font: Not Italic

Formatted: Font: Italic

Formatted: Font: Not Italic

Formatted: Font: Italic

Formatted: Font: Not Italic

Formatted: Font: Italic

Formatted: Font: Italic, Complex Script Font: Italic

Formatted: Font: Not Italic

Formatted: Font: Italic

Formatted: Font: Not Italic

Formatted: Font: Italic

Formatted: Font: Italic

Formatted: Font: Not Italic

Formatted: Font: Italic

Formatted: Font: Not Italic 
[23] M.D. Diaz, M. Fioroni, K. Burger, and S. Burger, Evidence of complete hydrophopic coating of bombesin by trifluoroethanol in aqueous solution: an NMR spectroscopic and molecular dynamics study, Chem. A Eur. J. 8 (2002), pp. 1663-1669.

[24] H. De Loof, L. Nilsson, and R. Rigler, Molecular dynamics simulation of galanin in aqueous and nonaqueous solution, J. Am. Chem. Soc. 114 (1992), pp. 4028-4035.

[25] H. Sticht, D. Willbold, and P. Roesch, Molecular dynamics simulation of equine infectious anemia virus Tat protein in water and in $40 \%$ trifluoroethanol, J. Biomolecular Struct. Dynamics 12 (1994), pp. 19-36.

[26] A.R. Van Buuren, and H.J. Berendsen, Molecular dynamics simulation of the stability of a 22-residue $\alpha$-helix and 30\% trifluoroethanol, Biopolymers 33 (1993), pp. 1159-1166.

[27] R. Chitra and P.E.J. Smith, A comparison of the properties of 2,2,2-trifluoroethanol and

\section{2,2,2-trifluoroethanol/water mixtures using different force fields, J. Chem. Phys. 115} (2001), pp. 5521-5530.

[28] D. Bemporad, C. Luttmann, and J.W. Essex, Computer simulation of small molecule permeation across a lipid bilayer: dependence on bilayer properties and solute volume, size, and cross-sectional area, Biophys. J. 87 (2004), pp. 1-13.

[29] P.W. Fowler, K. Balali-Mood, S. Deol, P.V. Coveney, and M.S.P. Sansom, Monotopic enzymes and lipid bilayers: a comparative study, Biochemistry, 46 (2007), pp. 3108-3115.

[30] D.P. Tieleman, B. Hess, and M.S.P. Sansom, Analysis and evaluation of channel models: simulations of alamethicin, Biophys. J. 83 (2002), pp. 2393-2407.

[31] D.P. Tieleman, H.J.C. Berendsen, and M.S.P. Sansom, Voltage-dependent insertion of alamethicin at phospholipid/water and octane/water interfaces, Biophys. J. 80 (2001), pp. 331-346.

[32] L.R. Forrest, A. Kukol, I.T. Arkin, D.P. Tieleman, and M.S.P. Sansom, Exploring models of the influenza A M2 channel: MD simulations in a phospholipids bilayer. Biophys. J. 78 (2000), pp. 55-69.

[33] L.J. McGuffin, K. Bryson, and D.T. Jones, The PSIPRED protein structure prediction server, Bioinformatics 16 (2000), pp. 404-405.

[34] J.A. Cuff, and G.J. Barton, Evaluation and improvement of multiple sequence methods for protein secondary structure prediction, Proteins 40 (1999), pp. 502-511.

[35] M. Ouali, and R.D. King, Cascaded multiple classifiers for secondary structure prediction, Prot. Sci. 9 (2000), pp. 1162-1176.

[36] B. Rost, PHD: predicting one-dimensional protein structure by profile-based neural networks, Methods Enzymol. 266 (1996), pp. 525-539.

Formatted: Font: Not Italic

Formatted: Font: Italic

Formatted: Font: Italic

Formatted: Font: Not Italic

Formatted: Font: Italic

Formatted: Font: Not Italic

Formatted: Font: Italic

Formatted: Font: Not Italic

Formatted: Font: Italic

Formatted: Font: Not Italic

Formatted: Font: Italic

Formatted: Font: Italic

Formatted: Font: Not Italic

Formatted: Font: Italic

Formatted: Font: Not Italic

Formatted: Font: Italic

Formatted: Font: Not Italic

Formatted: Font: Italic

Formatted: Font: Not Italic

Formatted: Font: Italic

Formatted: Font: Not Italic

Formatted: Font: Italic

Formatted: Font: Not Italic

Formatted: Font: Italic

Formatted: Font: Not Italic 
[37] Accelerys Inc. QUANTA/CHARMm, Version 28. San Diego, CA, http://www. accelerys.com

[38] W. Smith, C.W. Yong, and P.M. Rodger, DL POLY: application to molecular simulation, Mol. Simul. 28 (2002), pp. 385-471.

[39] D. Frishman, and P. Argos, Knowledge-based protein secondary structure assignment, Proteins 23 (1995), pp. 566-579.

[40] S. Nosé, A molecular dynamics method for simulations in the canonical ensemble, Molecular Physics 53 (1984), pp. 255-268.

[41] W.G. Hoover, Canonical dynamics: equilibrium phase-space distributions, Phys. Rev. A 31 (1985), pp. 1695-1697.

[42] M.P. Allen and D.J. Tildesley, Computer Simulation of Liquids, Clarendon Press, Oxford, 1987.

[43] A.D. MacKerell, Jr., D. Bashford, M. Bellott, R.L. Dunbrack, Jr., J.D. Evanseck, M.J. Field, S. Fischer, J. Gao, H. Guo, S. Ha, D. Joseph-McCarthy, L. Kuchnir, K. Kuczera, F.T.K. Lau, C. Mattos, S. Michnick, T. Ngo, D.T. Nguyen, B. Prodhom, W.E. Reiher, III, B. Roux, M. Schlenkrich, J.C. Smith, R. Stote, J. Straub, M. Watanabe, J. WiórkiewiczKuczera, D. Yin, and M. Karplus, All-Atom Empirical Potential for Molecular Modeling and Dynamics Studies of Proteins, J. Phys. Chem. B 102 (1998), pp. 3586-3616.

[44] H.C. Berendsen, J.P.M. Postma, W.F. van Gunsteren, and J. Hermans. 1981. Interaction models for water in relation to protein hydration. In Intermolecular Forces. Pullman B, Editor. Dordrecht, Reidel. 331-342.

[45] S. Rodziewicz-Motowidio, K. Brzozowski, A. Legowska, A. Liwo, J. Silbering, M. Smoluch, and K.J. Rolka, Conformational solution studies of neuropeptide gamma using CD and NMR spectroscopy, J. Pept. Sci. 8 (2002), pp. 211-226. [46] W. Humphrey, A. Dalke, and K. Schulten, VMD: visual molecular dynamics, J. Mol. Graph. 14 (1996), pp. 33-38.

\begin{tabular}{|c|}
\hline Formatted: Font: Italic \\
\hline Formatted: Font: Not Italic \\
\hline Formatted: Font: Italic \\
\hline Formatted: Font: Not Italic \\
\hline Formatted: Font: Italic \\
\hline Formatted: Font: Italic \\
\hline Formatted: Font: Not Italic \\
\hline Formatted: Font: Italic \\
\hline Formatted: Font: Italic \\
\hline Formatted: Font: Not Italic \\
\hline Formatted: Font: Italic \\
\hline Formatted: Font: Not Italic \\
\hline Formatted: English U.S. \\
\hline Formatted: Font: Italic, English U.S. \\
\hline Formatted: English U.S. \\
\hline $\begin{array}{l}\text { Formatted: Font: Not Italic, English } \\
\text { U.S. }\end{array}$ \\
\hline Formatted: Font: Not Italic \\
\hline Formatted: English U.S. \\
\hline $\begin{array}{l}\text { Deleted: Accelerys Inc. } \\
\text { QUANTA/CHARMm, Version 28. San } \\
\text { Diego, CA, http://www. accelerys.comII } \\
\text { Allen, M. P., and D. J. Tildesley. } 1987 . \\
\text { Computer Simulation of Liquids. } \\
\text { Clarendon Press, Oxford.II } \\
\text { Bemporad, D., C. Luttmann, and J. W. } \\
\text { Essex. 2004. Computer simulation of } \\
\text { small molecule permeation across a lipid } \\
\text { bilayer: dependence on bilayer properties } \\
\text { and solute volume, size, and cross- } \\
\text { sectional area. Biophys. J. 87:1-13.II } \\
\text { Berendsen H. C., J. P. M. Postma, W. F. } \\
\text { van Gunsteren, and J. Hermans. 1981. } \\
\text { Interaction models for water in relation to } \\
\text { protein hydration. In Intermolecular } \\
\text { Forces. Pullman B, Editor. Dordrecht, } \\
\text { Reidel. 331-342.II } \\
\text { Blobel, G., and B. Dobberstein. 1975. } \\
\text { Transfer of proteins across membranes. } \\
\text { Presence of proteolytically processed and } \\
\text { un processed nascent immunoglobulin } \\
\text { light chains on membrane-bound } \\
\text { ribosomes of murine myeloma. J. Cell } \\
\text { Biol. 67: 835-851.II } \\
\text { Brink, S., E. G. Bogsch, W. R. Edwards, } \\
\text { P. J. Hynds, and C. Robinson. 1998. } \\
\text { Targeting of thylakoid proteins by the } \\
\Delta \text { pH-driven twin-arginine translocation } \\
\text { pathway requires a specific signal } \\
\end{array}$ \\
\hline Formatted: English U.K. \\
\hline Formatted: Indent: Before: $0 \mathrm{pt}$ \\
\hline Formatted: English U.K. \\
\hline $\begin{array}{l}\text { Formatted: Font: Times New } \\
\text { Roman, English U.K. }\end{array}$ \\
\hline Formatted: English U.K. \\
\hline Formatted: English U.K. \\
\hline Formatted: English U.K. \\
\hline Formatted: English U.K. \\
\hline
\end{tabular}




\section{FIGURES CAPTURE}

Figure 1 Helix length (number of aminoacid residues) as a function of time for SufIs in

Deleted: 1

Formatted: English U.K.

aqueous solution.

Figure 2. Number of intramolecular hydrogen bonds as a function of time for SufIs in Deleted:

Formatted: English U.K.

aqueous solution.

Figure 3 Atom positional root-mean-square distance (RMSD) variations with the first

Figure 4 Helix length (number of aminoacid residues) versus time for SufIs in TFE.

Figure 5. Probability of finding each amino acid residue within an $\alpha$-helix structure for SufIs in TFE.

Figure 6 , Probability of finding each amino acid residue within an $\alpha$-helix structure calculated in portions of $1 \mathrm{~ns}$ for SufI-RR in TFE.

Figure 7. Snapshot of SufI-RR. $\operatorname{Arg}(6)$ and Gln(10) residues are shown in different colour in (a) and Cys(17) and Ile(14) in (b). The H-bonds are indicated in broken lines. The images were generated with $\mathrm{VMD}[46]$.

Figure 8 Number of intramolecular hydrogen bonds as a function of time for SufIs in TFE.

Figure 9. Atom positional root-mean-square distance (RMSD) variations for all atoms from the first configuration during the simulation for SufIs in TFE.

Figure 10. Atom positional root-mean-square distance (RMSD) variations for atoms in the different peptide regions from the first configuration during the simulation for SufIs in TFE.

Figure 11. Number of dihedral transitions for the backbone angles $\varphi$ and $\psi$ in each aminoacid residue for SufIs in TFE during the whole trajectory.

Figure 12. Helix length (number of aminoacid residues) as a function of time for SufIs in vacuum.

Figure 13. Probability of finding each amino acid residue within an $\alpha$-helix structure for SufIs in vacuum.
Deleted: 9

Deleted: Figure 103
Formatted: English U.K.

Deleted: (Humphrey et al, 1996)

Deleted: 8

Deleted: 8

Deleted: 9

Deleted: 9 


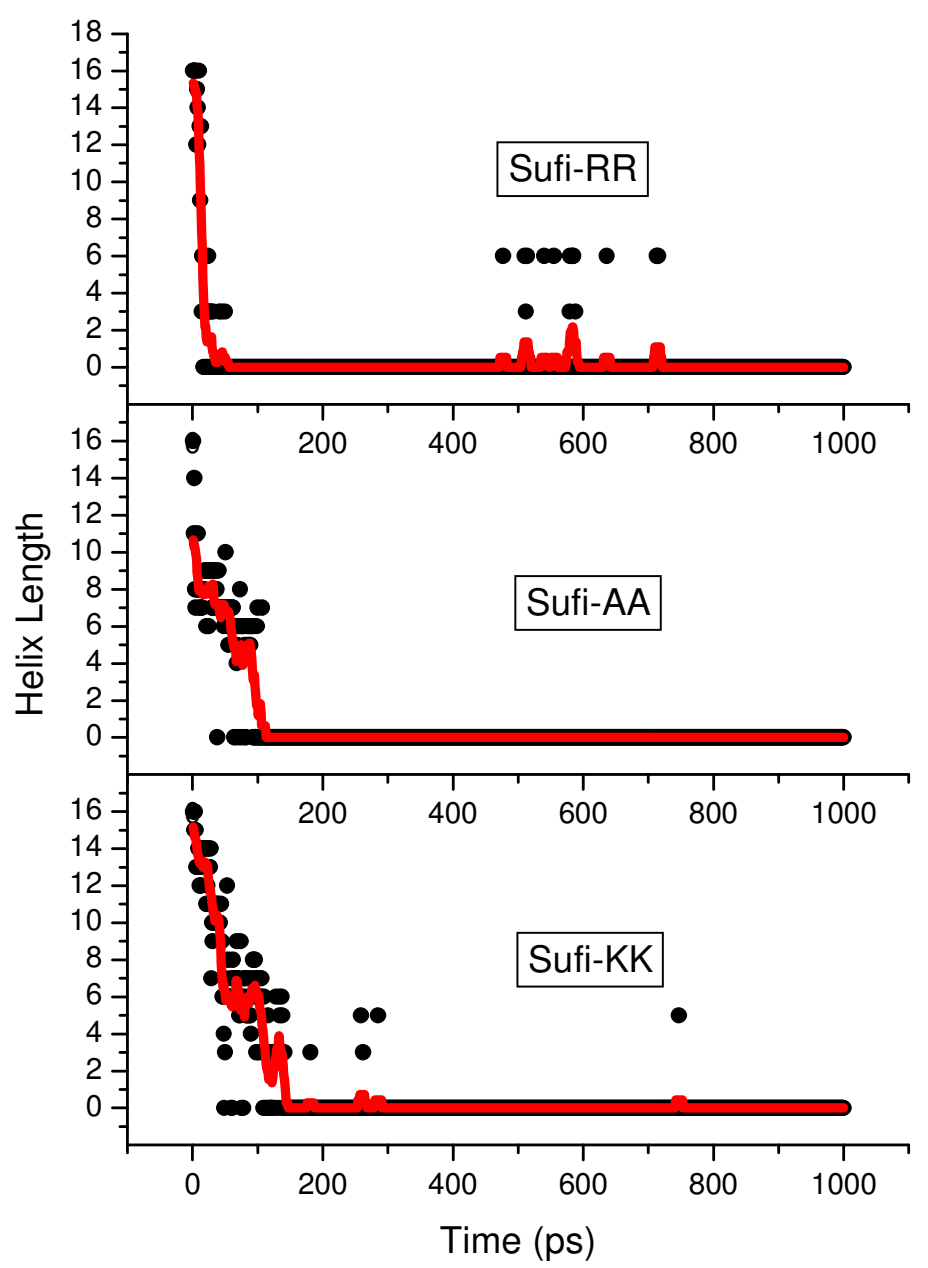

FIGURE 1 


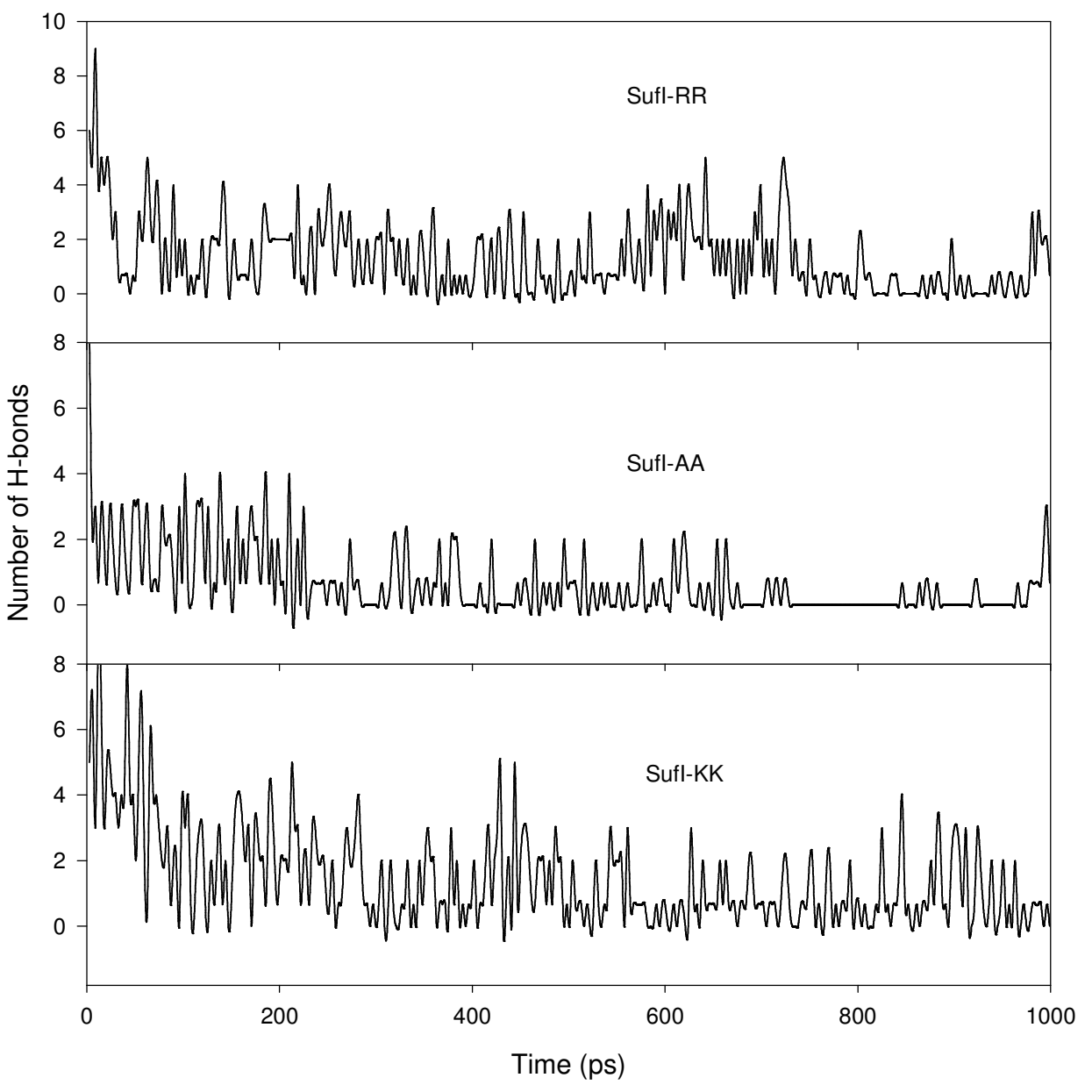

FIGURE 2 


\section{Page 19 of 34}

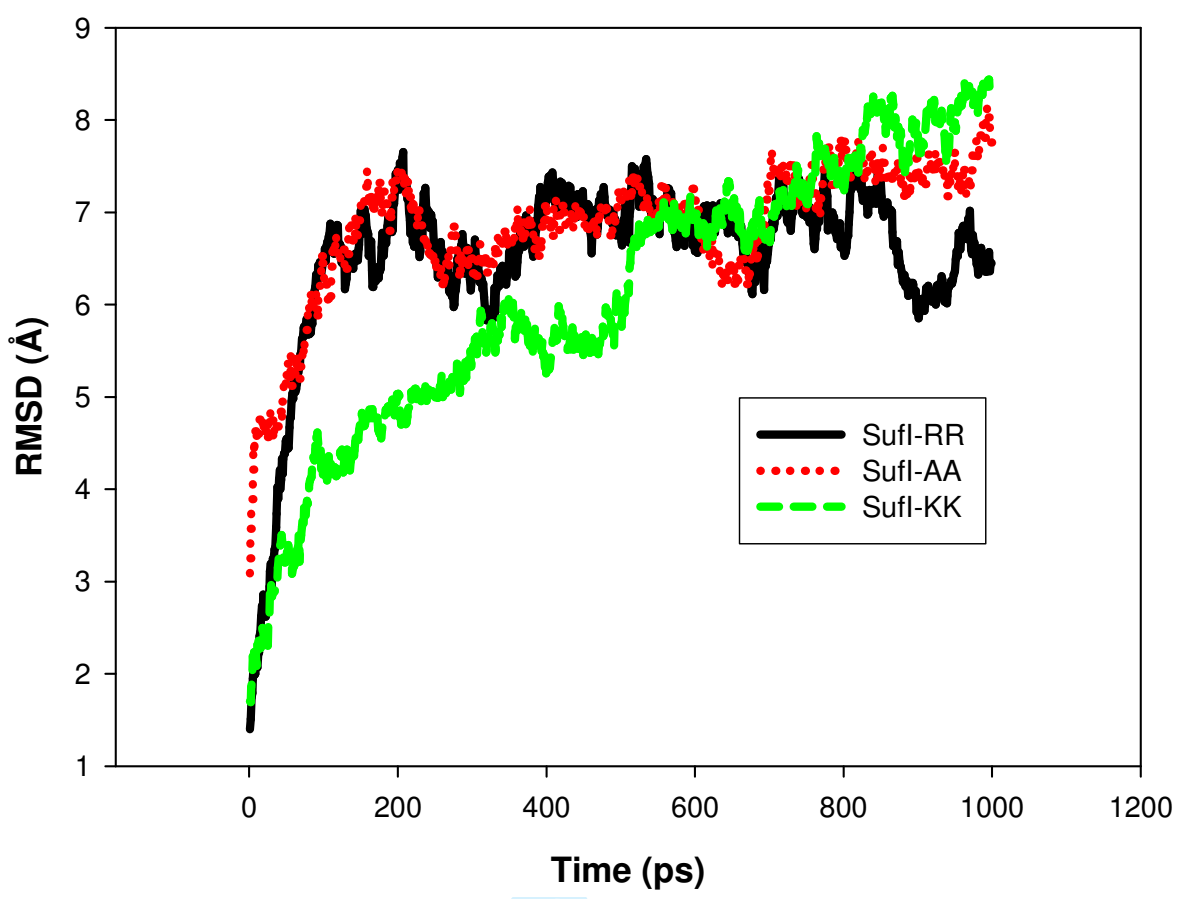

FIGURE 3 


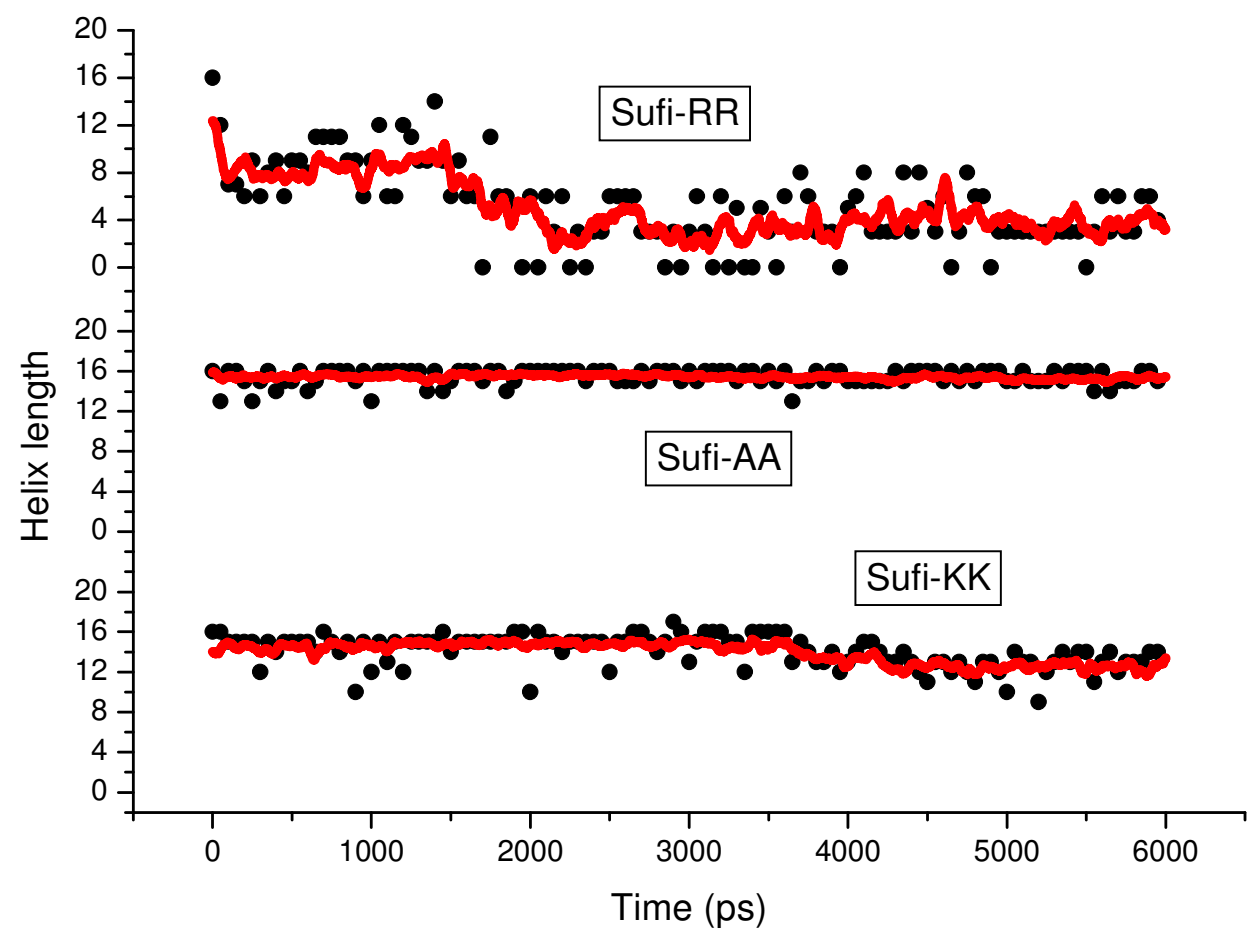

FIGURE 4 


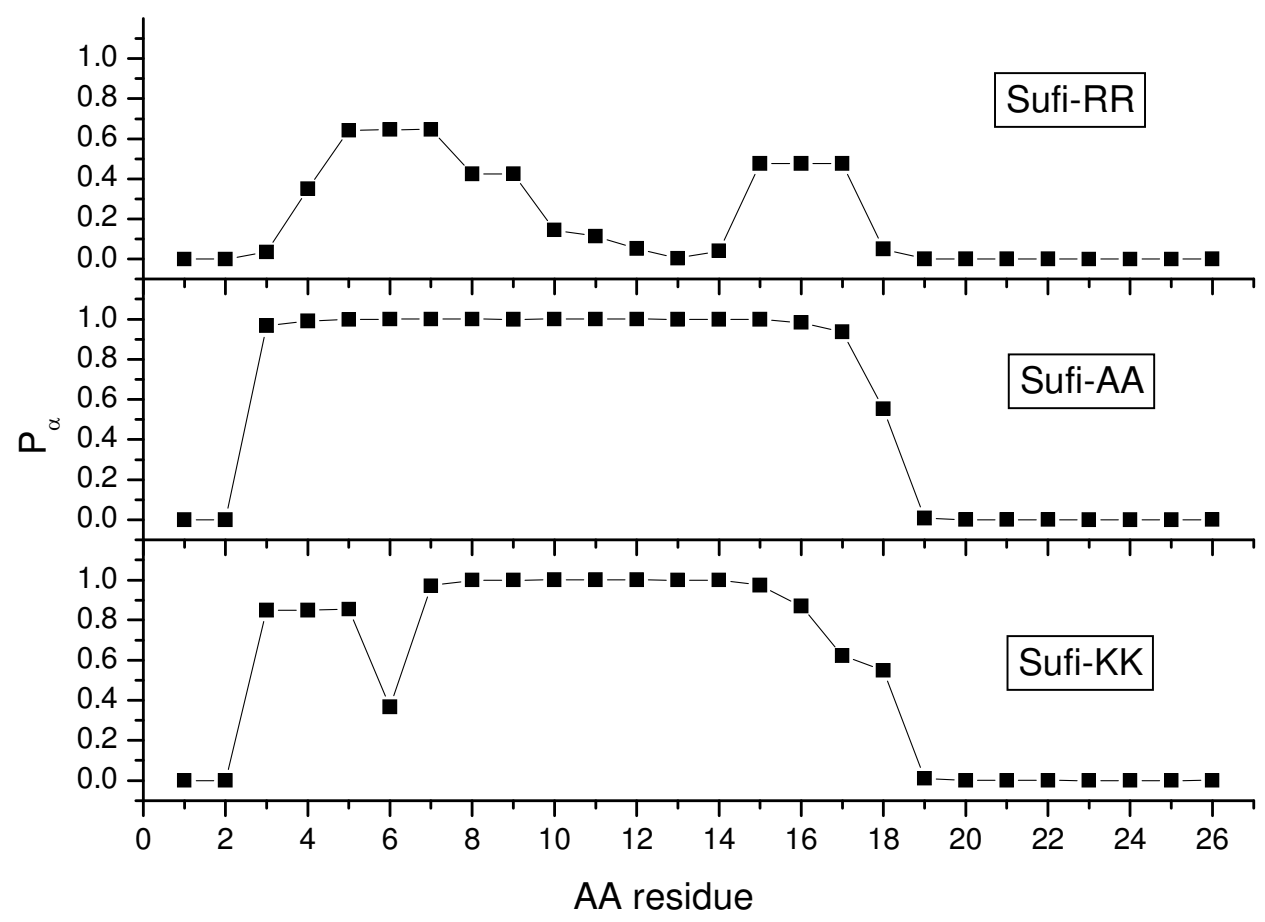

FIGURE 5 


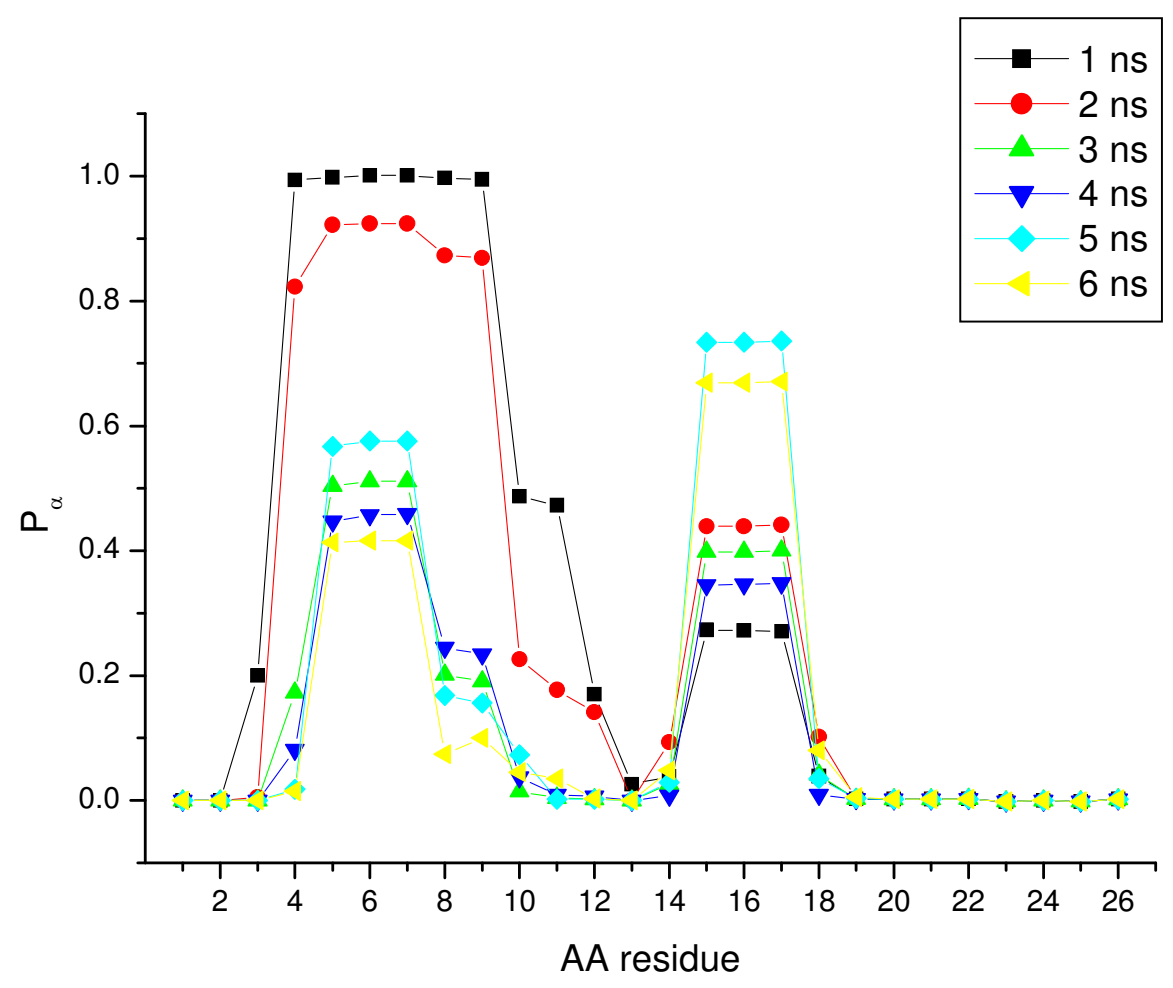

FIGURE 6 


\section{Page 23 of 34}

1
2
3
4
5
6
7
8
9
10
11
12
13
14
15
16
17
18
19
20
21
22
23
24
25
26
27
28
29
30
31
32
33
34
35
36
37
38
39
40
41
42
43
44
45
46
47
48
49
50
51
52
53
54
55
56
57
58
59
60
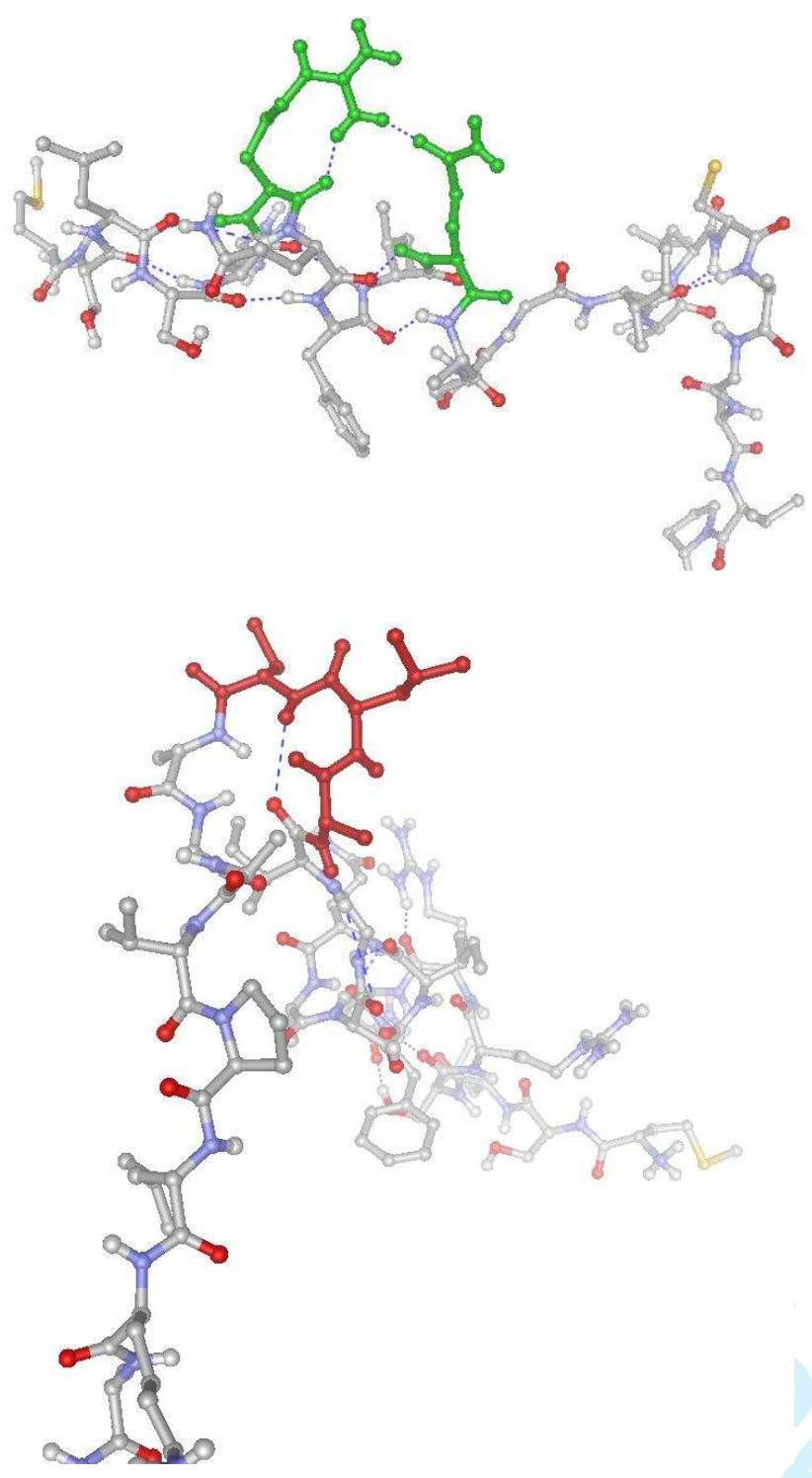

FIGURE 7

http://mc.manuscriptcentral.com/tandf/jenmol 


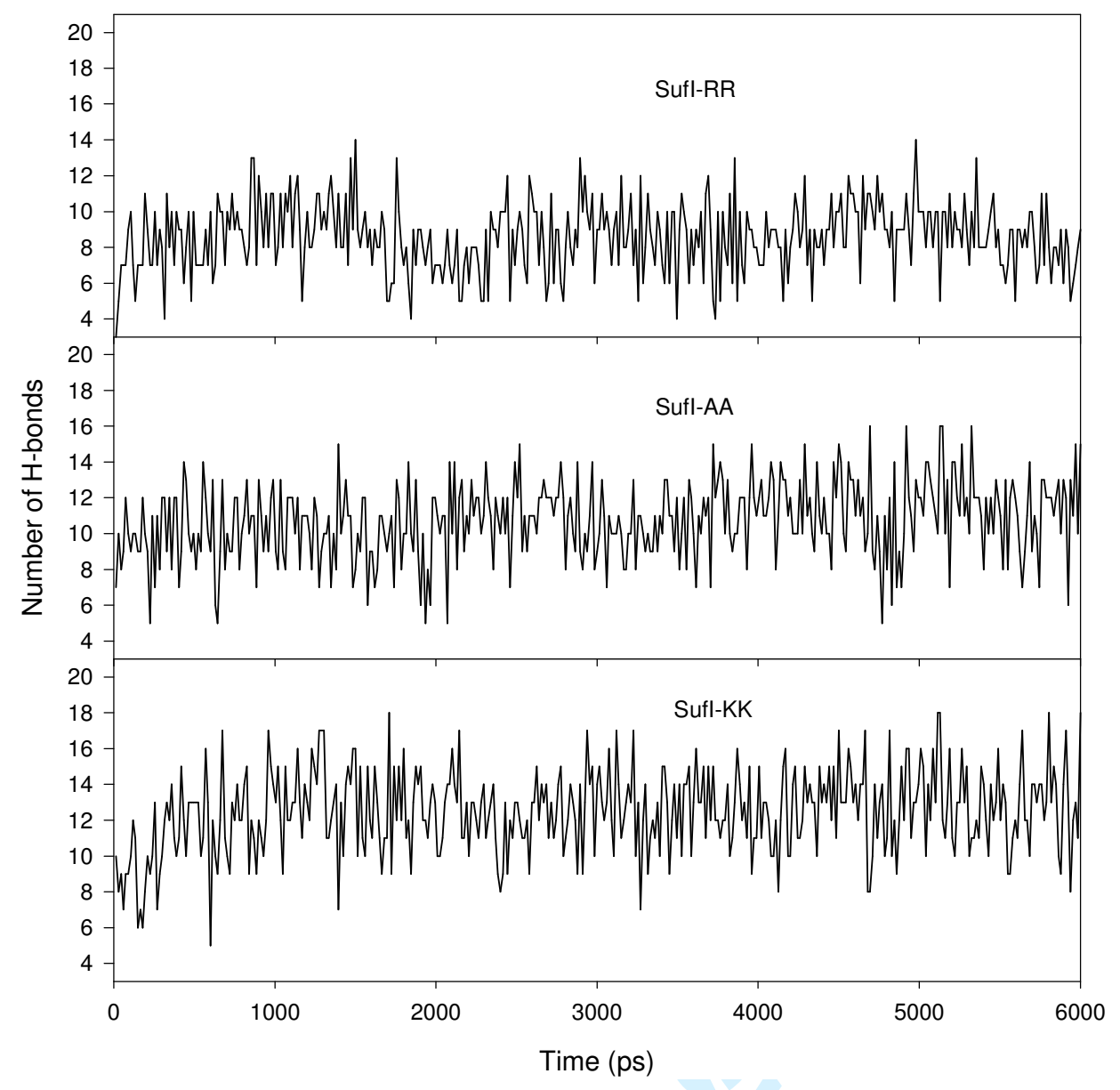

FIGURE 8 


\section{Page 25 of 34}

1
2
3
4
5
6
7
8
9
10
11
12
13
14
15
16
17
18
19
20
21
22
23
24
25
26
27
28
29
30
31
32
33
34
35
36
37
38
39
40
41
42
43
44
45
46
47
48
49
50
51
52
53
54
55
56
57
58
59
60

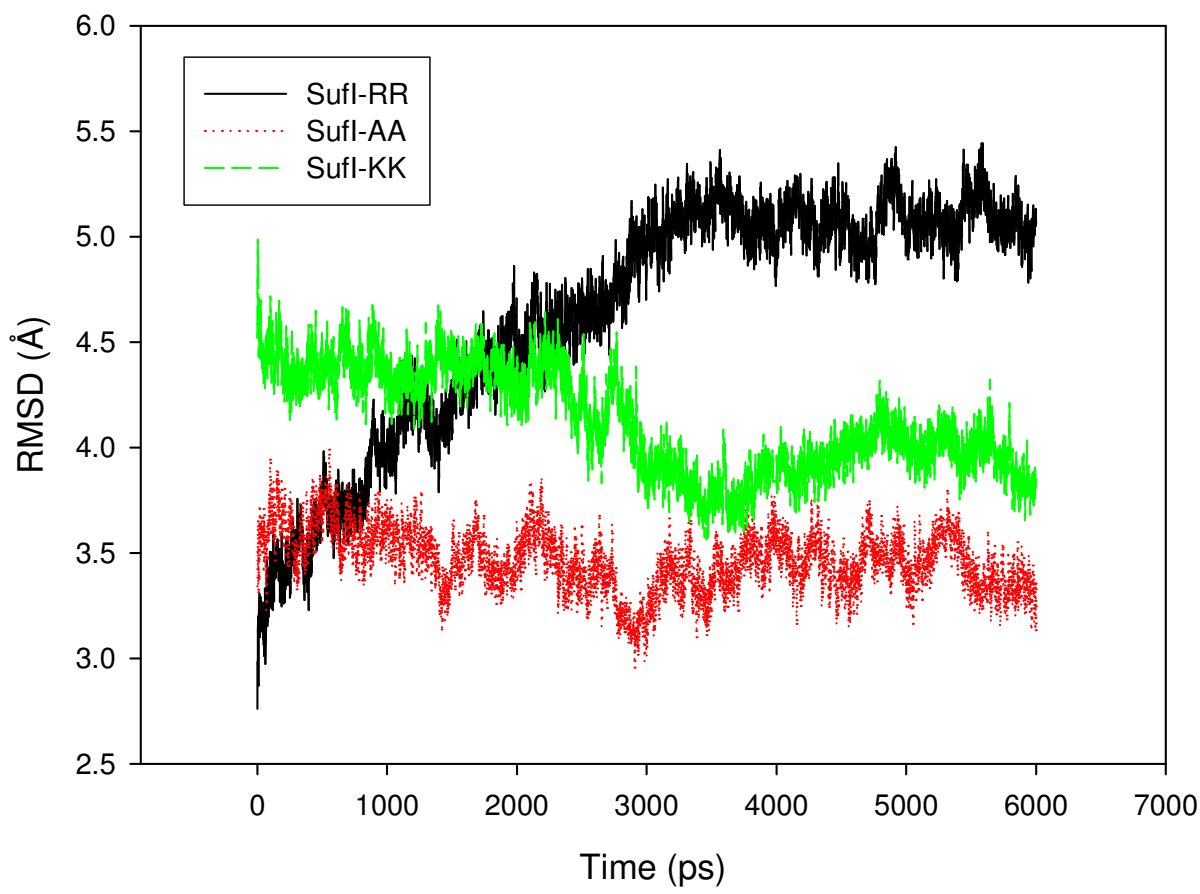

FIGURE 9 Formatted: English U.K. 


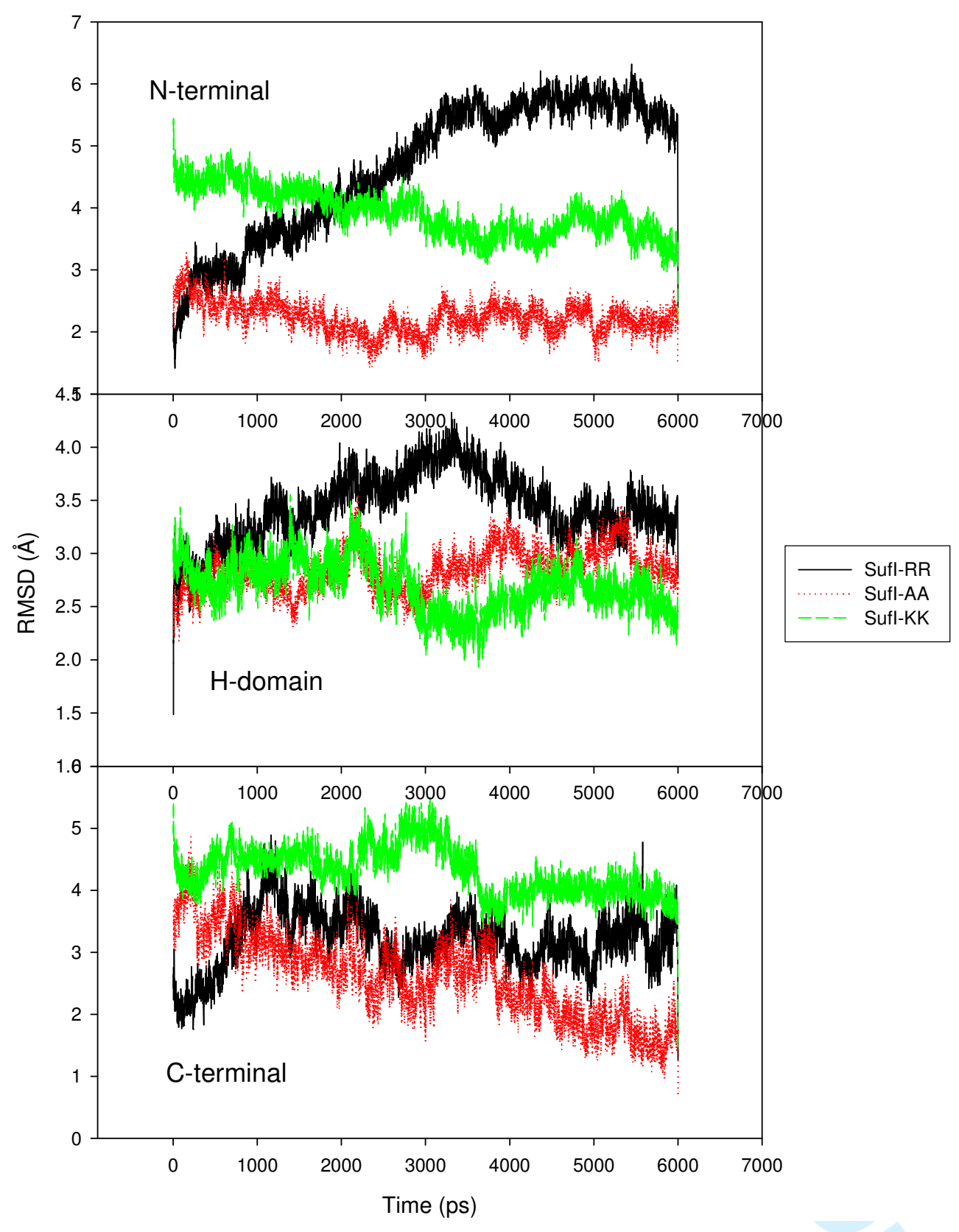

Figure 10 


\section{Page 27 of 34}

1
2
3
4
5
6
7
8
9
10
11
12
13
14
15
16
17
18
19
20
21
22
23
24
25
26
27
28
29
30
31
32
33
34
35
36
37
38
39
40
41
42
43
44
45
46
47
48
49
50
51
52
53
54
55
56
57
58
59
60

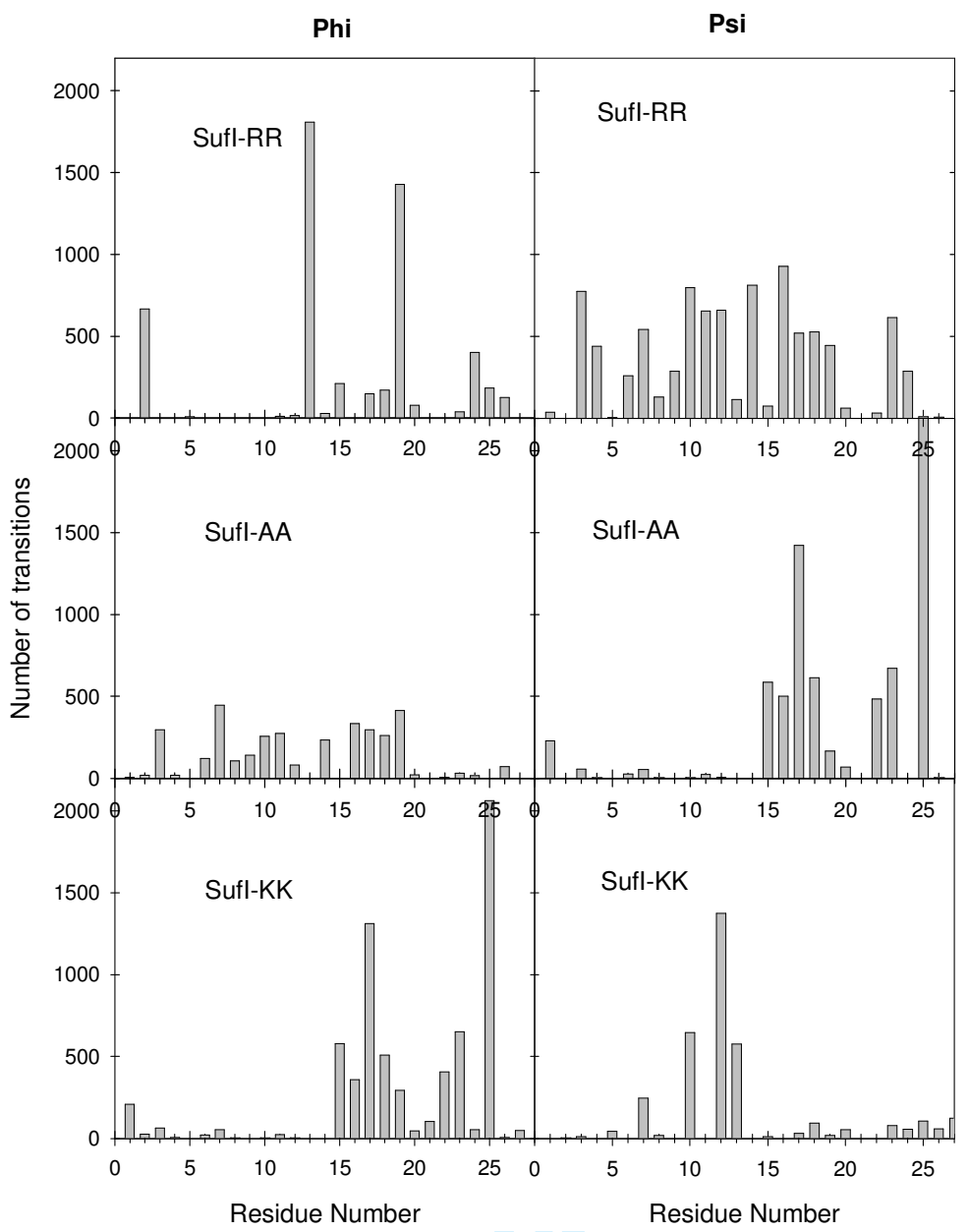

FIGURE 11___ Formatted: Font: $14 \mathrm{pt}$, Complex Script Font: 14 pt, English U.K. 


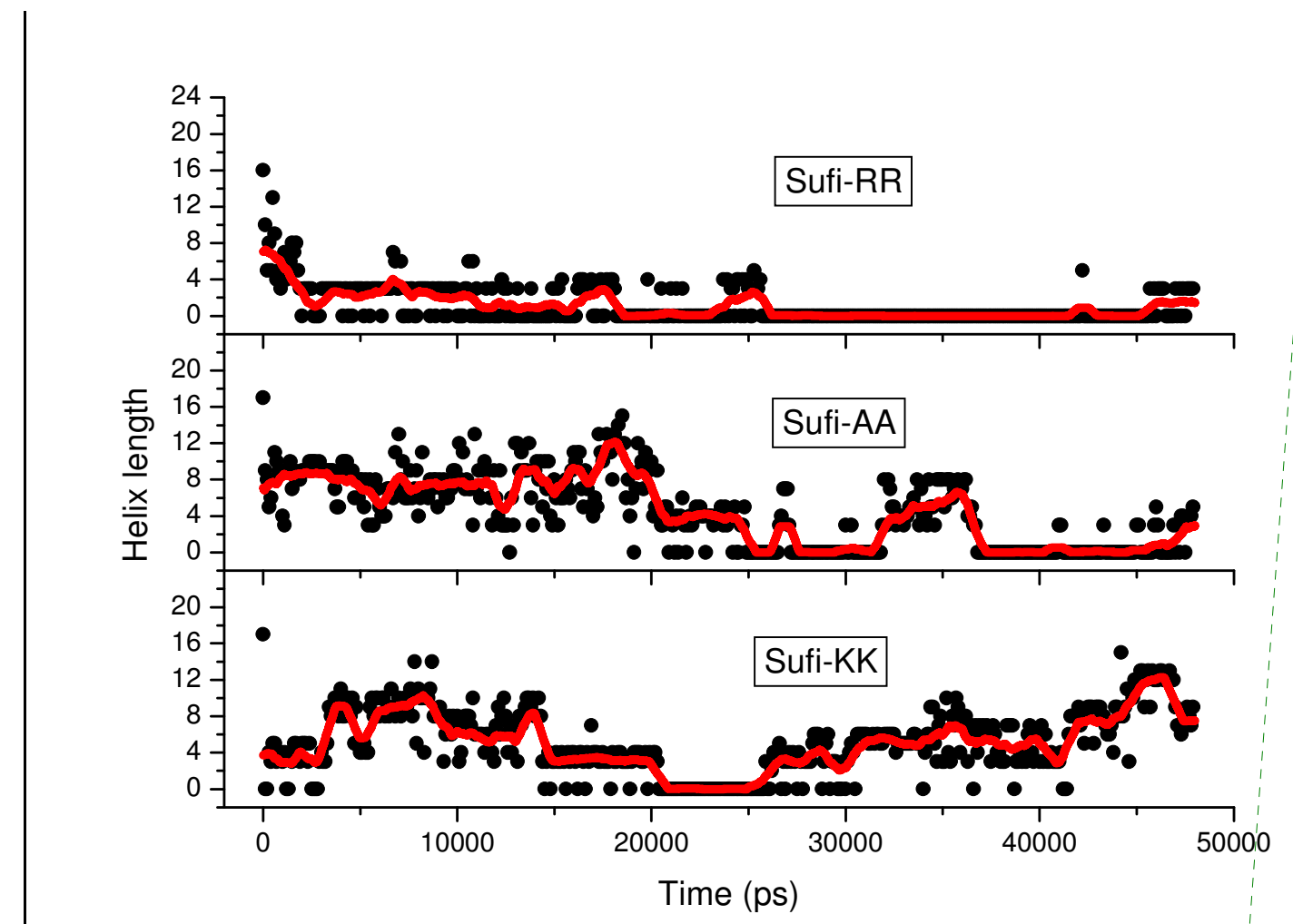

FIGURE 12 


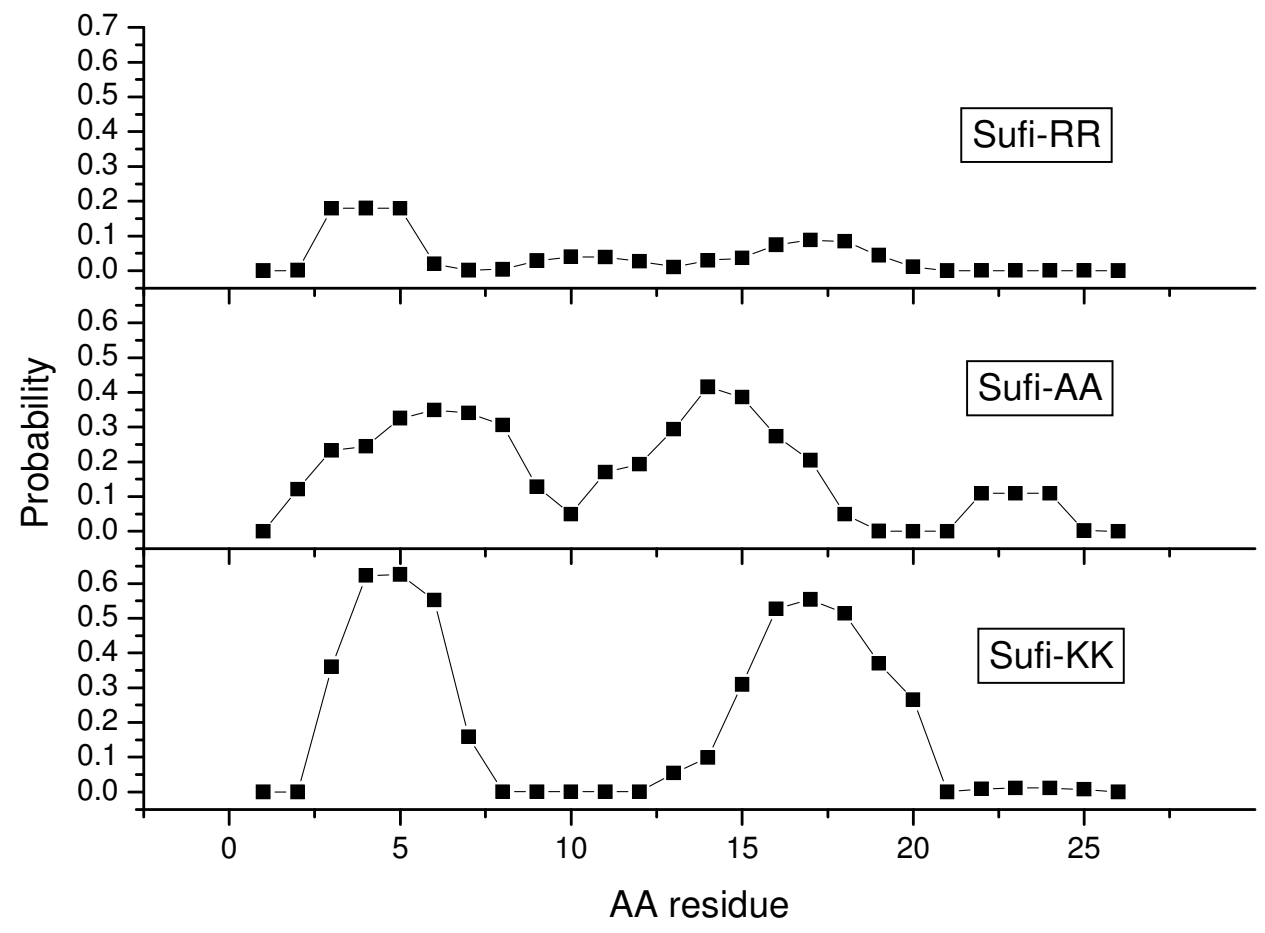

FIGURE 13 
Page 15: [1] Deleted $\quad$ smiguel $\quad 3 / 18 / 2009$ 4:03:00 PM

Accelerys Inc. QUANTA/CHARMm, Version 28. San Diego, CA, http://www. accelerys.com

Allen, M. P., and D. J. Tildesley. 1987. Computer Simulation of Liquids. Clarendon Press, Oxford.

Bemporad, D., C. Luttmann, and J. W. Essex. 2004. Computer simulation of small molecule permeation across a lipid bilayer: dependence on bilayer properties and solute volume, size, and cross-sectional area. Biophys. J. 87:1-13.

Berendsen H. C., J. P. M. Postma, W. F. van Gunsteren, and J. Hermans. 1981. Interaction models for water in relation to protein hydration. In Intermolecular Forces. Pullman B, Editor. Dordrecht, Reidel. 331-342.

Blobel, G., and B. Dobberstein. 1975. Transfer of proteins across membranes. Presence of proteolytically processed and un processed nascent immunoglobulin light chains on membrane-bound ribosomes of murine myeloma. J. Cell Biol. 67: 835-851.

Brink, S., E. G. Bogsch, W. R. Edwards, P. J. Hynds, and C. Robinson. 1998. Targeting of thylakoid proteins by the $\Delta \mathrm{pH}$-driven twin-arginine translocation pathway requires a specific signal in the hydrophobic domain in conjunction with the twin-arginine motif. FEBS Letts 434:425-430.

Chaddock, A.M., A. Mant, I. Karnauchov, S. Brink, R. G. Herrmann, R. B. Klösgen, and C. Robinson. 1995. A new type of signal peptide: central role of a twin-arginine motif in transfer signals for the $\triangle \mathrm{pH}$-dependent thylakoidal protein translocase. EMBOJ. $14: 2715-2722$

Chipot, C., B. Maigret, and A. Pohorille. 1999. Early events in the folding of an amphipathic peptide: a multinanosecond molecular dynamics study. Proteins: Structure, Function, and Genetics. 36:383-399.

Chitra, R., and P. E. J. Smith. 2001. A comparison of the properties of 2,2,2trifluoroethanol and 2,2,2-trifluoroethanol/water mixtures using different force fields. J. Chem. Phys. 115: 5521-5530.

Clark, S. A., and S. M. Theg. 1997. A folded protein can be transported across the chloroplast envelope and thylakoid membranes. Mol. Biol. Cell. 8:923-934.

Cuff, J. A., and G. J. Barton. 1999. Evaluation and improvement of multiple sequence methods for protein secondary structure prediction. Proteins. 40: 502-511. 
Dalbey, R. E., and C. Robinson. 1999. Protein translocation into and across the bacterial plasma membrane and the plant thylakoid membrane. Trends Biochem. Sci. 24: 17-22.

De Loof, H., L. Nilsson, and R. Rigler. 1992. Molecular dynamics simulation of galanin in aqueous and nonaqueous solution. J. Am. Chem. Soc. 114:4028-4035.

Diaz, M. D., M. Fioroni, K. Burger, and S. Burger. 2002. Evidence of complete hydrophopic coating of bombesin by trifluoroethanol in aqueous solution: an NMR spectroscopic and molecular dynamics study. Chem. A Eur. J. 8:1663-1669.

Domene, C., A. Grottesi, and M. S. P. Sansom. 2004. Filter flexibility and distortion in a bacterial inward rectifier $\mathrm{K}^{+}$channel: simulation studies of KirBac1.1. Biophys. $J$. $87: 256-267$.

Fioroni, M., M. D. Diaz, K. Burger, and S. Burger. 2002. Solvation phenomena of a tetrapeptide in water/trifluoroethanol and water/ethanol mixtures: a diffusion NMR, intermolecular NOE, and molecular dynamics study. J. Am. Chem. Soc. 124:77377744.

Forrest, L. R., A. Kukol, I. T. Arkin, D. P. Tieleman, and M. S. P. Sansom. 2000. Exploring models of the influenza A M2 channel: MD simulations in a phospholipids bilayer. Biophys. J. 78:55-69.

Frishman, D., and P. Argos. 1995. Knowledge-based protein secondary structure assignment. Proteins. 23:566-579.

Heins, L., I. Collinson, and J. Soll. 1998. The protein transport apparatus of chloroplast envelopes. Trends Plant Sci. 3: 56-61.

Hermann, J. M., and W. Neupert. 2000. Protein transport into mitochondria. Curr. Opin. Microbiol. 3: 210-214.

Hoover, W. G. 1985. Canonical dynamics: equilibrium phase-space distributions. Phys. Rev. A. 31:1695-1697.

Humphrey, W., A. Dalke, and K. Schulten. 1996. VMD: visual molecular dynamics. J. Mol. Graph. 14:33-38.

Hynds, P.J., D. Robinson, and C. Robinson. 1998. The Sec-independent twin-arginine translocation system can transport both tightly folded and malfolded proteins across the thylakoid membrane. J. Biol. Chem. 273:34868-34874. 
Iovino, M., M. Falconi, A. Marcellini, and A. Desideri. 2001. Molecular dynamics simulation of the antimicrobial salivary peptide histatin-5 in water and in trifluoroethanol: a microscopic description of the water destructuring effect. J. Peptide Research. 58:45-55.

Izard, J. W., and D. A. Kendall. 1994. Signal peptides: exquisitely designed transport promoters. Mol. Microbiol. 13: 765-773.

Jungnickel, B., T. Rapoport, and E. Hartmann. 1994. Protein translocation: common themes from bacteria to man. FEBS Lett. 346: 73-77.

La Rocca, P., P. C. Biggin, D. P. Tieleman, and M. S. P. Sansom. 1999. Simulation studies of the interaction of antimicrobial peptides and lipid bilayers. Biochim. Biophys. Acta. 1462:185-200.

MacKerell, A. D., Jr., D. Bashford, M. Bellott, R. L. Dunbrack, Jr., J. D. Evanseck, M. J. Field, S. Fischer, J. Gao, H. Guo, S. Ha, D. Joseph-McCarthy, L. Kuchnir, K. Kuczera, F. T. K. Lau, C. Mattos, S. Michnick, T. Ngo, D. T. Nguyen, B. Prodhom, W. E. Reiher, III, B. Roux, M. Schlenkrich, J. C. Smith, R. Stote, J. Straub, M. Watanabe, J. Wiórkiewicz-Kuczera, D. Yin, and M. Karplus. 1998. All-Atom Empirical Potential for Molecular Modeling and Dynamics Studies of Proteins. J. Phys. Chem. B. 102:3586-3616

McGuffin, L. J., K. Bryson, and D. T. Jones. 2000. The PSIPRED protein structure prediction server. Bioinformatics. 16:404-405.

Nosé, S. 1984. A molecular dynamics method for simulations in the canonical ensemble. Molecular Physics. 53:255-268.

Olivella, M., X. Deupi, C. Govaerts, and L. Pardo. 2002. Influence of the environment in the conformation of $\alpha$-helices studied by protein database search and molecular dynamics simulations. Biophys. J. 82:3207-3213.

Ouali, M., and R. D. King. 2000. Cascaded multiple classifiers for secondary structure prediction. Prot. Sci. 9:1162-1176.

Peter, C., X. Daura, and W. F. van Gunsteren. 2000. Peptides of aminoxy acids: a molecular dynamics simulation study of conformational equilibria under various conditions. J. Am. Chem. Soc. 122:7461-7466. 
Robinson, C., and A. Bolhuis. 2001. Protein targeting by the twin-arginine translocation pathway. Nature Rev. Mol. Cell. Biol. 2:350-355.

Roccatano, D., G. Colombo, M. Fioroni, and A. E. Mark. 2002. Mechanism by which 2,2,2-trifluoroethanol/water mixtures stabilize secondary structure formation in peptides: a molecular dynamics study. Proc. Natl. Acad. Sci. USA. 99:12179-12184.

Rodziewicz-Motowidio, S., K. Brzozowski, A. Legowska, A. Liwo, J. Silbering, M. Smoluch, and K. J. Rolka 2002. Conformational solution studies of neuropeptide gamma using CD and NMR spectroscopy. J. Pept. Sci. 8:211-226.

Rost, B. 1996. PHD: predicting one-dimensional protein structure by profile-based neural networks. Methods Enzymol. 266:525-539.

San-Miguel, M., R. Marrington, P. M. Rodger, A. Rodger, and C. Robinson. 2003. An Escherichia coli twin-arginine signal peptide switches between helical and unstructured conformations depending on the hydrophobicity of the environment. Eur. J. Biochem. 270:3345-3352.

Schatz, G., and B. Dobberstein. 1996. Common principles of protein translocation across membranes. Science. 271: 1519-1526.

Smith, W., C. W. Yong, and P. M. Rodger. 2002. DL_POLY: application to molecular simulation. Mol. Sim. 28: 385-471.

Stanley, N.R., T. Palmer, and B. C. Berks. 2000. The twin arginine consensus motif of Tat signal peptides is involved in Sec-independent protein targeting in Escherichia coli. J. Biol. Chem. 275:11591-11596.

Sticht, H., D. Willbold, and P. Roesch. 1994. Molecular dynamics simulation of equine infectious anemia virus Tat protein in water and in $40 \%$ trifluoroethanol. $J$.

Biomolecular Struct. Dynamics. 12:19-36.

Tieleman, D. P., and M. S. P. Sansom. 2001. Molecular dynamics simulations of antimicrobial peptides: from membrane binding to trans-membrane channels. Int. $J$. of Quantum Chem. 83:166-179.

Tieleman, D. P., B. Hess, and M. S. P. Sansom. 2002. Analysis and evaluation of channel models: simulations of alamethicin. Biophys. J. 83:2393-2407. 
Tieleman, D. P., H. J. C. Berendsen, and M. S. P. Sansom. 2001. Voltage-dependent insertion of alamethicin at phospholipid/water and octane/water interfaces. Biophys. J. 80:331-346.

Tieleman, D. P., M. S. P. Sansom, and H. J. C. Berendsen. 1999. Alamethicin helices in a bilayer and in solution: molecular dynamics simulations. Biophys. J. 76:40-49.

Tieleman, D. P., M. S. P. Sansom, and H. J. C. Berendsen. 1999. Alamethicin helices in a bilayer and in solution: molecular dynamics simulations. Biophys. J. 76:40-49.

Van Buuren, A. R., and H. J. Berendsen. 1993. Molecular dynamics simulation of the stability of a 22-residue $\alpha$-helix and 30\% trifluoroethanol. Biopolymers. 33:1159-1166. 